Biol. Stud. 2011: 5(1); 69-76 • DOI: https://doi.org/10.30970/sbi.0501.129

www.http://publications.Inu.edu.ua/journals/index.php/biology

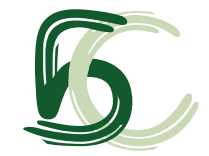

UDC $577.2+577.3-$

\title{
A COMPARISON OF PACLITAXEL AND VINBLASTINE INDUCED GIANT CELL FORMATION IN MURINE NK/Ly LYMPHOMA
}

\author{
R. O. Horbay', N. I. Kashchak ${ }^{2}$, R. S. Stoika² \\ ${ }^{1}$ Ivan Franko National University of Lviv, 4, Hrushevskyi St., Lviv 79005, Ukraine \\ ${ }^{2}$ Institute of Cell Biology NAS of Ukraine, 14-16, Drahomanov St., Lviv 79005, Ukraine \\ e-mail: rosthor@gmail.com
}

We compared giant cell formation in murine NK/Ly lymphoma under treatment with anticancer drugs - vinblastine or paclitaxel. It was found that vinblastine caused an appearance of bigger cells than paclitaxel did, whereas paclitaxel induced more rapid formation of giant cells than vinblastine did. Differences were also revealed in morphology of lymphoma cells treated with these anticancer drugs. While vinblastine induced more intensive membrane blebbing comparing with paclitaxel action, paclitaxel induced more pronounced cytosol vacuolization. Evaluation of trans-membrane potential based on studying mitochondrial accumulation of fluorescent dye Rhodamine-123, showed that paclitaxel caused more significant decrease of this potential comparing with vinblastine action. Role of the revealed peculiarities in the action of vinblastine and paclitaxel towards tumor cells are considered.

Key words: Murine NK/Ly lymphoma, vinblastine, paclitaxel, giant cells, membrane blebbing, cytosol vacuolization, trans-membrane potential.

It was shown that in populations of various cancer cells giant cells can appear spontaneously, and their number is significantly increased at tumor aging, drug treatment, or X-irradiation [10,12]. Calculation of giant cells in population was proposed for evaluation of efficiency of chemotherapy. After treatment of tumor cells with cytostatic drugs, the number of giant cells increased up to eight times [11, 12]. X-irradiation caused formation of giant cells that were 200 times bigger than the parental ones [4].

Giant cell transformation is strongly linked with changes in cytoskeleton, namely in microtubule system [2, 9, 11]. Microtubules are highly dynamic structures which constantly get longer and shorter [8]. These cytoskeletal proteins play an important role in many cellular events, particularly in cell division. Since cytoskeletal disorders can also result in cancer, tubulin is often targeted by anticancer chemotherapy [9]. Chemotherapy of cancer cells can induce either microtubular depolymerization or hyperpolymerization. In both cases, this results in cell cycle arrest which can occur in $\mathrm{G}_{0}-$ or $\mathrm{G}_{2} / \mathrm{M}$-phases [13]. Thus, the mitotic arrest is a common cause of giant cell formation [11, 14]. 
In this study, we used two known anti-tubulin agents possessing opposite effects towards tubulin, and also used as anticancer drugs. These are: vinblastine (alkaloid obtained from Catharanthus rosea) causing destabilization of microtubules, and paclitaxel (mitotic inhibitor obtained from Taxus brevifolia), stabilizing the microtubule structure [14].

Paclitaxel blocks cell ability to use cytoskeleton in a flexible manner. It binds to inner surface of the $\beta$-tubulin subunit along the length of microtubules, increasing in this way their affinity to neighboring molecules. At low concentration, paclitaxel stabilizes microtubules preventing cell cycle progression from metaphase to anaphase. While at higher concentration, this drug can stimulate microtubule polymerization. Thus, paclitaxel locks microtubules in place of their location, and cells loose their ability to disassemble. Furthermore, microtubules fix the position of chromosomes during mitosis. By stabilizing microtubules, paclitaxel blocks separation of daughter cells during mitosis. $[2,5,6]$.

Vinblastine binds to $\beta$-tubulin subunit and inhibits polymerization of microtubules. This leads to cell arrest at metaphase of mitosis or cell death. A decreased expression of class III $\beta$-tubulin was detected after vinblastine treatment [7]. At high concentration, vinblastine stimulates microtubule depolymerization and destroys mitotic spindle, whereas at low concentration, it blocks the mitotic progression. Unlike paclitaxel which weakly binds soluble $\beta$-tubulin, vinblastine tightly binds both microtubule-associated and soluble $\beta$-tubulin. By binding to a region called vinca domain, vinblastine inhibits lengthening and shortening of the microtubules. Microtubules enter an attenuated state which prevents an assembly of the mitotic spindle and reduces tension at the kinetochores of the chromosomes. This blocks their movement to cell spindle equator. Thus, cells get arrested in a state of progression from metaphase to anaphase of mitosis [1, 2, 3].

Different changes can occur in the giant cells that undergo inappropriate cell division and produce aneuploid daughter cells. Such enlarged cells can exit cell cycle without cell division or die during mitotic arrest. They can further develop as tetraploid cells and undergo apoptosis by exiting from the $G_{1}$-phase or escaping to $G_{1}$-phase and undergoing apoptosis in the interphase [1, 2].

Here we present our data on formation of giant cells and other changes in the murine NK/Ly lymphoma cells under paclitaxel or vinblastine treatment. Several differences were found in the cytomorphological characteristics of these tumor cells under their treatment with mentioned anticancer drugs.

\section{MATERIALS AND METHODS}

NK/Ly lymphoma was passaged by the intraperitoneal inoculation of 25 million cells into C57 black 4-month old mice. Animal weighting was performed every 24 hours after tumor cell inoculation. On day 7-10, when animal weight increased by $50-60 \%$, mice drainage was performed (the amount of taken ascite was no less than $10 \mathrm{ml}$ ). The diameter of the parental non-treated NK/Ly lymphoma cells equaled $12.7 \mu \mathrm{m}$. To obtain a population of giant cells with diameter $\geq 17 \mu \mathrm{m}$, an injection of $1 \%$ vinblastine solution $(50 \mu \mathrm{g})$ or $1 \%$ paclitaxel solution $(60 \mu \mathrm{g})$ was performed 3 days before drainage. In another experiment, in 72 hours after vinblastine injection (50 $\mu \mathrm{g}$ per mouse) different doses of paclitaxel were applied (starting with $3 \mu \mathrm{g}$ per $\mathrm{ml}$ of ascite). All doses were selected experimentally. Lymphoma cells present in the ascite were used for study.

ISSN 1996-4536 • Біологічні Студії / Studia Biologica • 2011 • Том 5/№1 • С. 69-76 
To evaluate the morphological changes in the drug-treated cells, cell size and the percentage of giant cells was measured in the hemocytometer chamber. Cells were stained with acridine orange (incubation of $3 \times 10^{6} \mathrm{cells} / \mathrm{ml}$ for $10 \mathrm{~min}$ in $0.1 \%$ acridine orange solution), DAPI (incubation of $3 \times 10^{6} \mathrm{cells} / \mathrm{ml}$ for $10 \mathrm{~min}$ with methanol (1 volume of methanol and 2 volumes of cell suspension), and further incubation for $10 \mathrm{~min}$ in $0.1 \%$ DAPI), Hoechst 33342 (incubation of $3 \times 10^{6}$ cells $/ \mathrm{ml}$ for $10 \mathrm{~min}$ in $0.1 \%$ Hoechst 33342), or fixed with methanol and stained for $45 \mathrm{~min}$ with $5 \%$ Giemsa-Romanovsky dye. Rhodamine-123 staining was performed to check mitochondria membrane potential $\left(3 \times 10^{6} \mathrm{cell} / \mathrm{s} / \mathrm{ml}\right.$ were incubated with $1 \mu \mathrm{g} / \mathrm{ml}$ of Rhodamine- 123 for $\left.30 \mathrm{~min}\right)$. Light and fluorescent microscopies (MikMed 2, Russia), as well as electron microscopy (PEM100, Ukraine) were carried out. Studies were conducted in 1, 3, 6, 12, 24, 48, 72, 96, 120 and 144 hours of mice treatment with used cytostatic drugs.

Each experiment noted in this work was repeated three times. All conducted procedures were performed in accordance with the stipulations of Helsinki Declaration and the policy statement for care and use of laboratory animals. This was done under the control of Bio-Ethical Committee at the Institute of Cell Biology, NAS of Ukraine.

\section{RESULTS AND DISCUSSION}

Fig. 1 presents data on size distribution of murine NK/Ly lymphoma cells in control and vinblastine- or paclitaxel-treated mice. One can see that maximal number of giant cells was achieved in $24 \mathrm{~h}$ of paclitaxel treatment and in $72 \mathrm{~h}$ of vinblastine treatment. The average diameter of giant cells in the paclitaxel-treated animals equaled $18.2 \mu \mathrm{m}$ with maximum size of $40 \mu \mathrm{m}$. In 96 hours after the paclitaxel injection to NK/Ly tumorbearing mice, most lymphoma cells in the ascite were back to smaller size of $13.3 \mu \mathrm{m}$ that is close to size of the parental cells $(12.7 \mu \mathrm{m})$. The mitotic spindle was rarely observed in the paclitaxel-treated cells, while some of the vinblastine-treated lymphoma cells reached $85 \mu \mathrm{m}$ in diameter and $10.3 \%$ of them possessed a mitotic spindle. The biggest amount of giant cells equaled $82.1 \%$, and it was reached in 72 hours after the

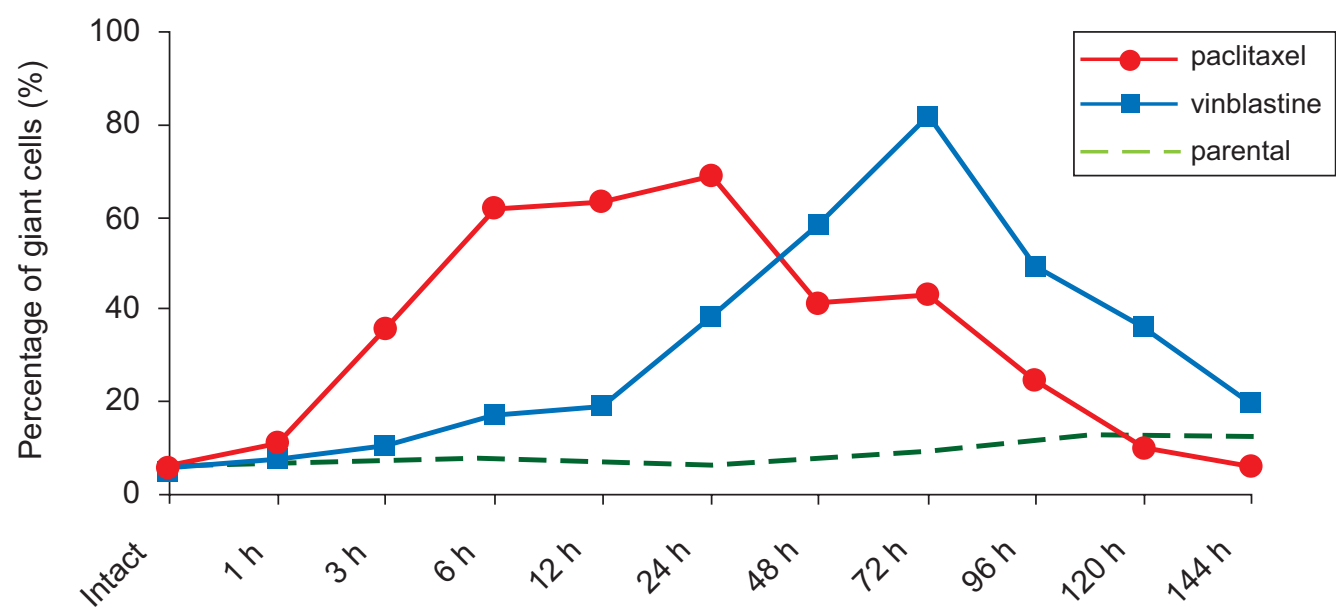

Fig. 1. Time dependent dynamics of number of giant cells in the murine NK/Ly lymphoma under paclitaxel or vinblastine treatment

Рис. 1. Залежна від часу динаміка кількості гігантських форм клітин мишачої лімфоми NK/Ly за дії вінбластину чи паклітакселу 
vinblastine injection (average size - $19.5 \mu \mathrm{m}$ ) (fig. 1). Thus, cells subjected to vinblastine treatment were not only larger, but also possessed a longer lifespan.

While a start of increase in number of giant NK/Ly cells was observed as soon as 3 hours after paclitaxel injection, a significant increase in number of vinblastine-induced giant cells can be seen much later ( 24 hours after drug injection). Under paclitaxel and vinblastine treatment cells were 3.5 and 7 times enlarged in their diameter, respectively (fig. 2). Giant cells whose appearance was induced by vinblastine, were almost twice bigger in diameter than the giant cells induced by paclitaxel. It should be noted that second injection of paclitaxel $(30 \mu \mathrm{g})$ killed all animals, while even after 6 vinblastine injections (25 $\mu \mathrm{g}$ each) all animals survived.

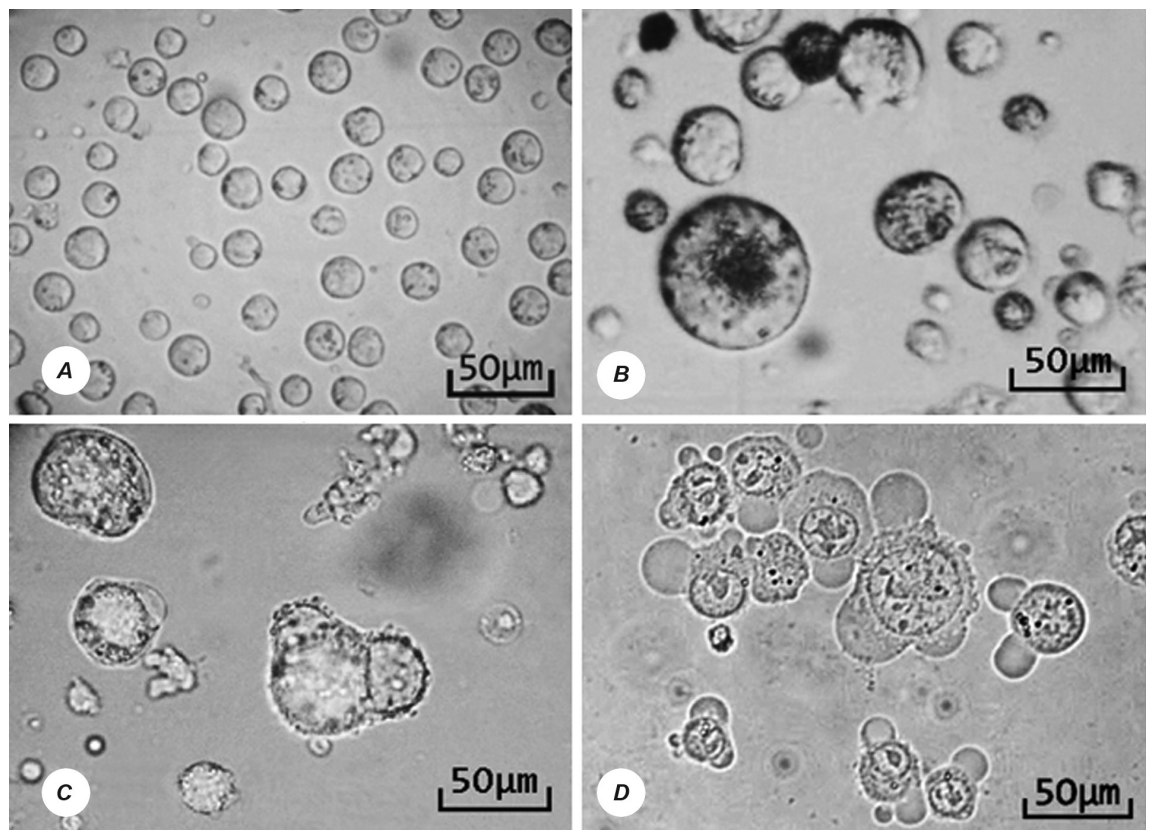

Fig. 2. Light microscopy of the parental $(A)$, paclitaxel-treated $(B)$, vinblastine-treated $(C)$, and combined vinblastine and paclitaxel-treated $(D)$ murine NK/Ly lymphoma cells

Рис. 2. Світлова мікроскопія клітин мишачої лімфоми NK/Ly батьківського типу $(A)$, а також клітин, оброблених паклітакселом $(B)$, вінбластином $(C)$ та обома препаратами $(D)$

We found that in addition to affecting lymphoma cell morphology, the applied drugs significantly reduced the number of the NK/Ly lymphoma cells in ascite (from $160 \mathrm{mln} /$ $\mathrm{ml}$ to $30 \mathrm{mln} / \mathrm{ml}$ under 24 hour paclitaxel treatment, and from $170 \mathrm{mln} / \mathrm{ml}$ to $55 \mathrm{mln} / \mathrm{ml}$ under 72 hour vinblastine treatment).

Almost all vinblastine-treated cells had various membrane defects (fig. 2), firstly membrane blebbing, whereas an appearance of vacuoles in cytosol was the most pronounced change in the paclitaxel-treated cells (fig. 3). It should be noted that in the paclitaxel-treated cells, there appeared either huge membrane blebs which could be 3 times bigger than the whole cell, or numerous smaller blebs on cell surface (fig. 2). In addition, nucleus asymmetry, abnormal accumulation of chromatides, and nucleus membrane defects were observed under vinblastine or/and paclitaxel treatment (fig. 3).

ISSN 1996-4536 • Біологічні Студії / Studia Biologica • 2011 • Том 5/№1 • C. 69-76 

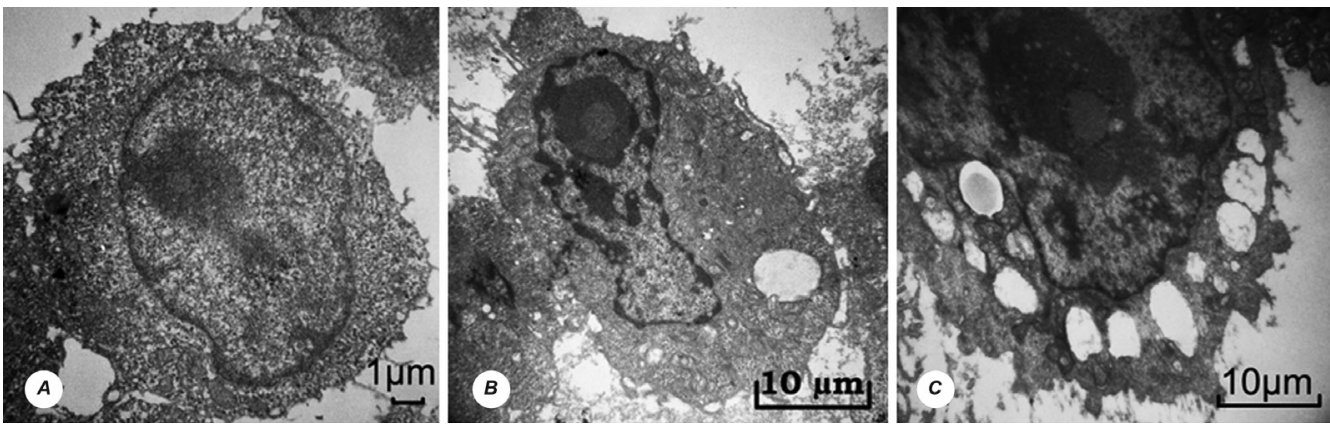

Fig. 3. Electron microscopy of the parental $(A)$, and paclitaxel- $(B)$ or vinblastine- $(C)$ treated murine NK/Ly lymphoma cells

Рис. 3. Електронна мікроскопія клітин батьківського типу $(A)$ мишачої лімфоми NK/Ly, а також цих клітин після дії паклітакселу $(B)$ чи вінбластину $(C)$

Rhodamine-123 accumulation in mitochondria indicates normal membrane potential in cells, while a diffused localization of this fluorescent dye suggests a decrease of this potential that is characteristic for the apoptotic cells [15]. We found that giant lymphoma cells appearing under the action of vinblastine, do not differ significantly from the parental lymphoma cells in Rhodamine-123 accumulation in mitochondria, while the paclitaxel treatment led to a decrease in membrane potential if judged by this indicator (fig. 4). Of course, other pro-apoptotic indicators should be also evaluated for taking

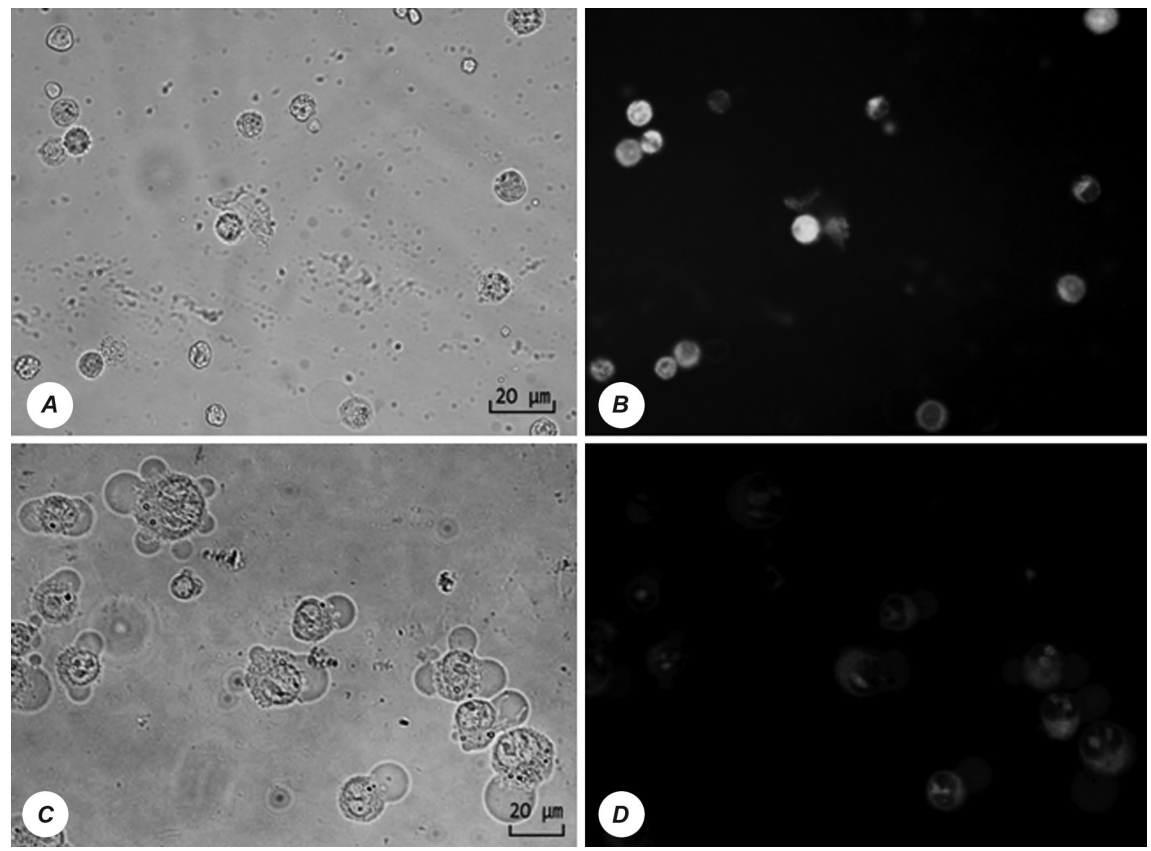

Fig. 4. Rhodamine 123 staining of the parental $(A, B)$ and giant $(C, D)$ murine NK/Ly lymphoma cells which appeared under vinblastine-paclitaxel co-treatment of tumor-bearing mice (see Materials and Methods)

Рис. 4. Фарбування Родаміном-123 клітин мишачої лімфоми NK/Ly: батьківські клітини $(A, B)$ та клітини після сумісної дії на них вінбластину і паклітакселу $(C, D)$ (див. розділ Матеріали і методи) 
a final conclusion on different effects of vinblastine and paclitaxel towards trans-membrane potential in mitochondria.

We found that paclitaxel injection ( $30 \mu \mathrm{g}$ per mouse) in 72 hours after vinblastine injection (50 $\mu \mathrm{g}$ per mouse) led to massive blebbing of lymphoma cells already in 1 hour of paclitaxel action. One can see that almost all lymphoma cells obtained from animals treated with both used drugs, underwent giant cell transformation and membrane blebbing (fig. 4). The average size of such treated cells equaled $20.3 \mu \mathrm{m}$ and $94.2 \%$ of all cells contained blebs. These blebs were much bigger than those which appeared under treatment of tumor-bearing animals with only vinblastine or paclitaxel. This suggests that the mechanisms of action of vinblastine and paclitaxel differ considerably, since paclitaxel intensified significantly vinblastine action towards blebbing of target cells. It should be noted that in most cells obtained from mice treated with both vinblastine and paclitaxel, the size of the blebs overcome the size of the cells. These cells treated with two used anticancer drugs, also possessed a decreased Rhodamine-123 accumulation in mitochondria, comparing with such accumulation in mitochondria of cells obtained from the vinblastine-treated mice.

\section{CONCLUSION}

Morphological changes induced by paclitaxel and vinblastine in the murine NK/Ly lymphoma cells differ considerably. Both paclitaxel and vinblastine induced plasma membrane blebbing, cytosolic vacuolization, and changes in cell nucleus. However, in the case of vinblastine treatment, membrane blebbing was more pronounced, while in the case of paclitaxel action, cytosolic vacuolization was much better expressed. These data suggest different mechanisms in targeting cytoskeletal protein $\beta$-tubulin by these anticancer drugs. Cytochemical study of the character of Rhodamine-123 accumulation in mitochondria of cells treated with these two anticancer drugs indicates more pronounced effect of the paclitaxel than of the vinblastine towards decreasing transmembrane potential. Further studies on discriminating between the mechanisms of paclitaxel and vinblastine actions towards tumor cells are in progress.

1. Gascoine K.E., Taylor S.S. How do anti-mitotic drugs kill cancer cells? Journal of Cell Science, 2009; 122(15): 2579-2585.

2. Jordan M.A., Wilson L. Microtubules as a target for anticancer drugs. Nature Reviews. Cancer, 2004; 4(4): 253-265.

3. Wang L.G., Liu X.M., Kreis W., Budman D.R. The effect of antimicrotubule agents on signal transduction pathways of apoptosis: a review. Cancer Chemotherapy and Pharmacology, 1999; 44(5): 355-361.

4. Tolmach L.J., Marcus P.L. Development of X-ray induced giant HeLa cells. Experimental Cell Research, 1960; 20: 350-360.

5. Brito D. A., Yang Z., and Rieder C. L. Microtubules do not promote mitotic slippage when the spindle assembly checkpoint cannot be satisfied. J. Cell Biol, 2008; 182: 623-629.

6. McGrogana B.T., Gilmartina B., Carneyc D.N., McCann A. Taxanes, microtubules and chemoresistant breast cancer. Biochimica et Biophysica Acta, 2008; 1785(2): 96-132.

7. Kavalaris M., Sasha Tait A., Walsh B.J. et al. Multiple microtubule alterations are associated with Vinca alkaloids resistance in human leukemia cells. Cancer Research, 2001; 61: 58035809 .

ISSN 1996-4536 • Біологічні Студії / Studia Biologica • 2011 • Том 5/№1 • C. 69-76 
8. Mitchison T.J., Kirschner M. Dynamic instability of microtubule growth. Nature (Lond.), 1984; 312: 237-242.

9. Jordan M.A., Wilson L. Microtubules and actin filaments: dynamic targets for cancer therapy. Curr. Opin. Cell Biol, 1998; 10: 123-130.

10. Lootsik M.D., Boiko N.M., Lootsik M.M. Investigation of therapeutic effect of saponin from greater celandine on a model of murine lymphoma NK/Ly. $2^{\text {nd }}$ Ukrainian congress for cell biology (Book of Abstracts), 2007; 1: 103 (in Ukrainian)

11. Horbay R.O., Manko B.O., Manko V.V. et al. Respiration characteristics of mitochondria in parental and giant transformed cells of murine Nemeth-Kellner lymphoma, Cell Biol. Int, 2011: a submitted article.

12. Lutsyk M.M., Yashchenko A.M. Quantitive method of evaluation of tumor cells damage under the influence of antitumor drugs in vivo by cytochemical staining for protein. Reports of Morphology, 2009; 15 (1): 188-192.

13. Erenpreisa J.A., Cragg M.S. Mitotic death: a mechanism of survival? A review. Cancer Cell Int, 2001; 1:1.

14. Vakifahmetoglu H., Olsson M., Zhivotovsky B. Death through a tragedy: mitotic catastrophe, Cell Death and Differentiation, 2008; 15: 1153-1162.

15. Kaminskyy V., Kulachkovskyy O., Stoika R. A decisive role of mitochondria in defining rate and intensity of apoptosis induction by different alkaloids. Toxicology Letters, 2008; 177: 168-181.

\title{
ПОРІВНЯЛЬНА ХАРАКТЕРИСТИКА ГІГАНТОКЛІТИННОЇ ТРАНСФОРМАЦІЇ В МИШАЧІЙ ЛІМФОМІ NK/LY ЗА ДIÏ ПАКЛІТАКСЕЛУ I ВІНБЛАСТИНУ
}

\author{
P. О. Горбай', Н. І. Кащак², Р. С. Стойка² \\ ${ }^{1}$ Львівський національний університет імені Івана Франка \\ вул. Грушевського, 4, Львів 79005, Україна \\ ${ }^{2}$ Інститут біології клітини НАН України, вул. Драгоманова, 14-16, Львів 79005, Україна \\ e-mail: rosthor@gmail.com
}

Ми порівняли гігантоклітинну трансформацію клітин мишачої лімфоми NK/Ly після дії протипухлинних препаратів - вінбластину та паклітакселу. Було виявлено, що за дії вінбластину утворювались більші у розмірі клітини, тоді як паклітаксел викликав швидше утворення гігантських клітин. Також помічено зміни в морфології лімфомних клітин після дії даних протипухлинних препаратів. У той час як вінбластин викликав інтенсивніше утворення пухирців на мембрані клітини, паклітаксел інтенсивніше індукував вакуолізацію в цитозолі. Було проведено вимірювання трансмембранного потенціалу мітохондрій за накопиченням тут родаміну-123 і показано, що паклітаксел викликав значне зниження даного показника порівняно з вінбластином. Обговорено роль виявлених особливостей у дії вінбластину і паклітакселу на пухлинні клітини.

Ключові слова: Мишача лімфома NK/Ly, вінбластин, паклітаксел, гігантські клітини, мембранні пухирці, цитозольна вакуолізація, трансмембранний потенціал. 


\title{
СРАВНИТЕЛЬНАЯ ХАРАКТЕРИСТИКА ГИГАНТОКЛЕТОЧНОЙ ТРАНСФОРМАЦИИ В МЫШИНОЙ ЛИМФОМЕ NK/LY ПРИ ДЕЙСТВИИ ПАКЛИТАКСЕЛА И ВИНБЛАСТИНА
}

\begin{abstract}
Р. О. Горбай', Н. И. Кащак², Р. С. Стойка
${ }^{1}$ Львовский национальный университет имени Ивана Франко ул. Грушевского, 4, Львов 79005, Украина ${ }^{2}$ Институт биологии клетки НАН Украины, ул. Драгоманова, 14-16, Львов 79005, Украина e-mail: rosthor@gmail.com

Мы сравнили гигантоклеточную трансформацию клеток мышиной лимфомы NK/Ly после действия противоопухолевых препаратов - винбластина и паклитаксела. Было обнаружено, что при действии винбластина образовывались большие по размерам клетки, в то время как паклитаксел быстрее вызывал образование гигантских клеток. Также были отмечены изменения в морфологии лимфомных клеток после действия на них данных противоопухолевых препаратов. В то время, как винбластин вызывал более интенсивное образование пузырей на мембране клетки, паклитаксел индуцировал вакуолизацию в цитозоле. Было проведено измерение трансмембранного потенциала митохондрий по накоплению родамина-123 и показано, что паклитаксел вызывает значительное снижение данного позазателя по сравнению с таким же действием винбластина. Обсуждается роль выявленных особенностей в действии винбластина и паклитаксела на опухолевые клетки.
\end{abstract}

Ключевые слова: Мышиная лимфома NK/Ly, винбластин, паклитаксел, гигантские клетки, мембранные пузыри, цитозольная вакуолизация, трансмембранный потенциал.

Одержано: 04.03.2011

ISSN 1996-4536 • Біологічні Студії / Studia Biologica • 2011 • Том 5/№1 • С. 69-76 